Article

\title{
Characterization and Treatment Proposals of Shipboard Slop Wastewater Contaminated by Hydrocarbons
}

\author{
Riccardo Campo * (D), Maria Gabriella Giustra, Mauro De Marchis (D), Gabriele Freni \\ and Gaetano Di Bella \\ Faculty of Engineering and Architecture, University "Kore" of Enna, 94100 Enna, Italy; \\ mariagabriella.giustra@unikore.it (M.G.G.); mauro.demarchis@unikore.it (M.D.M.); \\ gabriele.freni@unikore.it (G.F.); gaetano.dibella@unikore.it (G.D.B.) \\ * Correspondence: riccardo.campo@unikore.it; Tel.: +39-0935-536-439
}

Received: 31 March 2017; Accepted: 30 July 2017; Published: 4 August 2017

\begin{abstract}
Shipboard slop wastewaters are produced by the activity of washing of oil tankers with seawater, and are characterized by high salinity and hydrocarbons. In this context, harbor authorities are forced to respect the international regulation IMO-MARPOL 73/78 and they must treat slop wastewater before discharging to the sea. This study compared data from three stand-alone treatments working with the same real slop wastewater: (1) a chemical treatment of coagulation-flocculation with aluminum sulphate as coagulant and an anionic flocculant (A57), (2) a physical treatment of adsorption on granular activated carbon (GAC), (3) two biological treatments represented by a membrane bioreactor (MBR) and a moving bed biofilm reactor (MB-MBR). GAC treatment registered the highest removal efficiency of total petroleum hydrocarbons ( $\eta \mathrm{TPH}$ ) next to $85 \%$, since the activated carbon had excellent adsorption properties towards organic substances. The coagulation-flocculation treatment reported the lowest $\eta \mathrm{TPH} \approx 57 \%$ due to the presence of emulsified hydrocarbons that were not affected by the coagulant and flocculant action, so remaining in liquid phase. $\eta \mathrm{TPH} \approx 70 \%$ obtained with MB-MBR fed with $100 \%$ volume of slop, suggested biomass acclimation to salinity and hydrocarbons. Based on the results of each process, three main treatment chains are proposed depending on the hydrocarbons load of the real slop wastewater.
\end{abstract}

Keywords: slop; salinity; hydrocarbons; coagulation-flocculation; MBR; GAC

\section{Introduction}

Oil has always been the primary engine of the modern world economy. Many activities related to the oil extraction and transportation utilize high volumes of water for their realization and, as direct consequence, this implies an increasing production of wastewater often rich in recalcitrant and slowly biodegradable compounds, such as hydrocarbons [1].

From this point of view, in the last years, the environmental awareness is progressively increased, thus resulting in a higher investigation and publications production over time (Figure 1a) and worldwide (Figure 1b), concerning the topic of "hydrocarbons wastewater treatment". To date, several papers were published concerning this topic, with a considerable increase in the last 20 years. This is probably due to a more sensitive and strict environmental legislation encouraging the scientific researchers to develop new treatment systems in order to meet the regulations. 


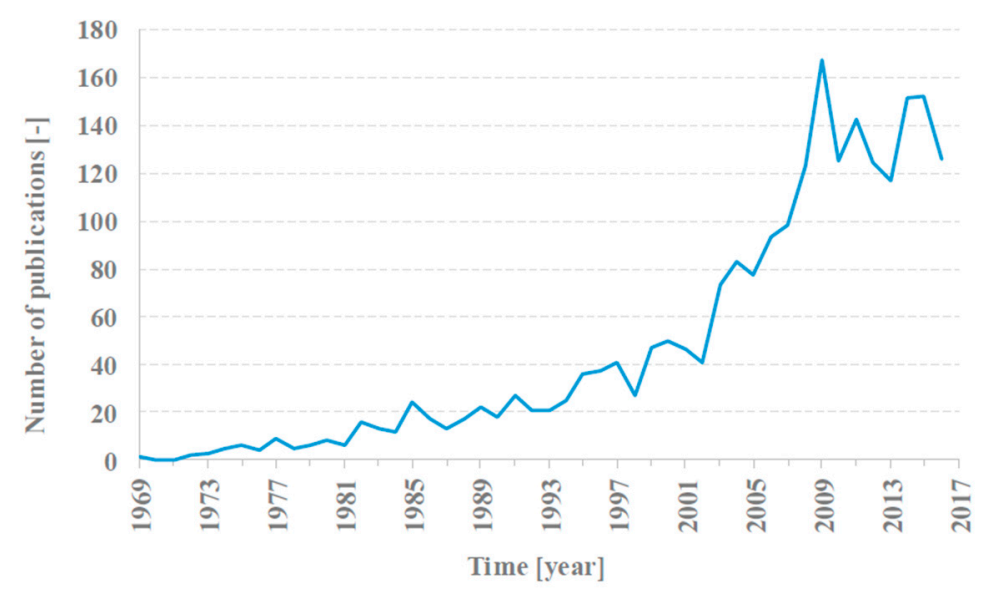

(a)

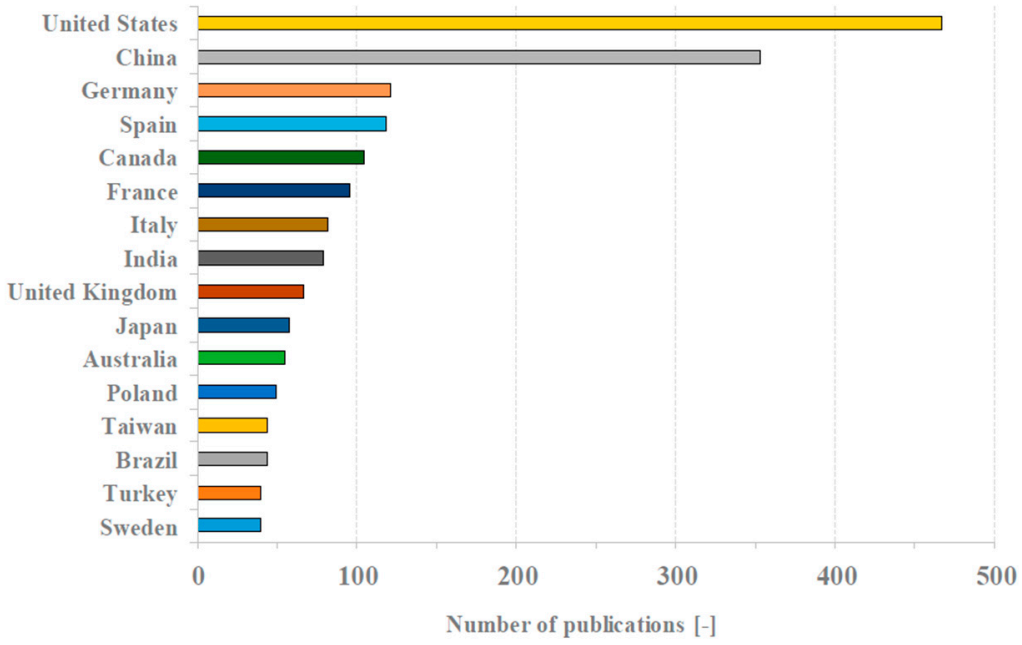

(b)

Figure 1. Trend of scientific production concerning treatment of wastewater contaminated by hydrocarbons over time (a) and worldwide (b) (Scopus ${ }^{\circledR}$ —Copyright $@ 2017$ Elsevier B.V).

The extraction activity of oils and gas from reservoirs needs huge volumes of saline water properly injected underground to sustain the pressure and to enhance the oil recovery from the source. This results in a mixture of saline water and hydrocarbons, named "produced water" [1] whose discharge could be of great environmental impact. Basically, Dickhout et al. (2017) [2] in a recent review, define produced water as an oil-in-water emulsion, where the oily phase is dispersed in the aqueous phase, stabilized by surfactants. The composition of product water is highly variable with the oil field ages. The main components of produced water are dispersed oil, dissolved organics, suspended solids and dissolved inorganics, but also process chemicals such as corrosion inhibitors, biocides and extraction enhancers can be added during the oil extraction process [3]. All these molecules act as surfactants and confer stability to the emulsion of produced water, hindering the treatment. Once extracted, the crude oil needs to be transported from the extraction wells to the oil refineries and, once obtained the final product, it has to be transported from the refineries to the distributors. Today, the only way to move crude oil across the oceans on a global scale is represented by oil tankers. This constitutes a potential severe environmental risk, since, in the past, serious accidents have resulted in the spillage of oil at sea [4]. Moreover, between the operations of fill and draw of crude oil from and into the oil tankers, the hulls are washed with seawater in order to remove a higher portion of hydrocarbons from the walls of the tanker. This activity produces a specific shipboard industrial wastewater named 
"slop", which is mainly characterized by high salinity and hydrocarbons concentration [5-7]. Due to its polluting characteristics, slops cannot be directly discharged to the sea. However, it should be emphasized that despite these general characteristics (salinity and high content of hydrocarbons), a high variability of the organic contaminants and their concentrations is often registered, which in some cases may affect the specific treatability of slop wastewater.

In this context, harbour authorities are required to comply with stringent regulations laid down by the International Maritime Organization (IMO), as the international convention MARPOL 73/78 [4]. This regulation defines a group of special areas, among all Mediterranean Sea, where the direct discharge of oil hydrocarbons is strictly limited to $5 \mathrm{ppm}$ in order to protect the marine ecosystem. This implies that harbour authorities have to apply adequate treatments of shipboard slop, before the discharge into the sea. All the countries reported in Figure $1 \mathrm{~b}$ have signed the IMO/MARPOL 73/78 (http:/ / www.imo.org/en/About/Conventions/StatusOfConventions/Documents/status-x.xls), so they are subjected to same regulations concerning the treatment and the discharge of oily wastewater. The difference in number of publications, is probably due to the political-economic strategy of each country that could be based on the more or less massive use of oil and hydrocarbons that, consequently, imply a more or less production of oily wastewater.

Even though several studies have been carried out about produced water treatment [1,2,8-17], shipboard slops wastewater treatment is a topic worthy of further investigation also in light of the lack of information and research articles regarding their treatment [5-7]. Among the difficulties relating to the treatment of such wastewater, the characterization is a first obstacle related to the proper nature of wastewater, rich in floating oils and emulsified phases [5], which hinds the repeatability and the reproducibility of analytical methods. In literature, three main treatment proposals are usually recommended to manage industrial wastewater contaminated by hydrocarbons, such as: chemical, physical and biological treatments [1].

Chemical treatments are commonly preferred for their high removal efficiencies towards recalcitrant compounds [5]. A very effective chemical technology is represented by coagulation-flocculation which can be used to remove suspended and colloidal particles, but is not effective for removing dissolved constituents [1]. The application of an inorganic mixed metal composed by iron $(\mathrm{Fe})$, magnesium $(\mathrm{Mg})$ and aluminium $(\mathrm{Al})$ as polynuclear polymer named FMA, reported good coagulation, de-oiling and scale inhibition properties particularly in produced water of high SS levels of 50-400 mg/L FMA. SS and oil can be removed to levels $>92 \%$ and $97 \%$, respectively [18]. On the other hand, Houcine (2002) in a study [19] used spillsorb, calcite, and lime to remove heavy metals from produced water. Results showed that lime removal efficiency is greater $(>95 \%)$ than with others and that it was an economical chemical. However, despite of their high removal efficiencies, chemical treatments may involve high production of chemical sludge rich in metals, and high operational costs related to chemicals consumption and disposal.

Among the physical treatments, one of the most used for its high removal efficiencies in the field of oily wastewater treatment is the adsorption on activated carbon provided as powder (PAC) or as granules (GAC). Organic compounds and some heavy metals adhere to porous media of carbon surfaces [20]. Activated carbon can remove soluble hydrocarbons including benzene, toluene, ethylbenzene, and xylene (BTEX), as well demonstrated by Roccaro et al. (2014) [21]. Replacement and disposal of exhausted carbon is quite expensive and the spent carbon may have to be handled as hazardous waste. Moreover, the relatively fast saturation of the GAC stresses the need for an economic regeneration process in order to make the adsorption process feasible. Therefore, in order to face these drawbacks, Roccaro et al. (2014) [21] investigated the feasibility of offline bioregeneration (OBR) of the saturated carbon. They found that recovery of the adsorption capacity was $50 \%$ and $57 \%$ for toluene and benzene, respectively. However, GAC was not fully regenerated by OBR even though a significant part of the adsorption capacity was recovered. Among other adsorbent materials, Fakhru'l-Razi et al. (2009) [1] report that organoclay can remove insoluble free hydrocarbons that contribute to total petroleum hydrocarbons $(\mathrm{TPH})$ and oil and greases $(\mathrm{O} \& \mathrm{G})$ measurement. Organoclay is produced 
by combining sodium montmorillonite clay with a cationic quaternary amine salt. When organoclay is used in conjunction with activated carbon, hydrocarbon concentration falls below water quality standards [22]. Zeolites are often used as ion-exchange resins. Use of hydrophobic zeolite pellets in a fixed bed to adsorb dissolved organic compounds in produced water is a used technique [20]; on the other hand, Means et al. (1992) [23] proposed a resin-filled column to remove soluble organic compounds. In both methods, acid backwash and solvents can regenerate the adsorbers. At this purpose, the performance of the adsorbers is affected by several parameters, such as temperature and $\mathrm{pH}$, suspended oil, low heavy metal concentration and organic-metal complex, dissolved contaminants (organics chemicals), and high salinity [20]. Suspended particles in raw wastewater may plug the media and reduce removal efficiency. On the other hand, also in this case, chemical wastes from regeneration of adsorbers are the new problems to face with these methods, since with physical processes only a mass transfer is obtained, without any transformation [1].

As an alternative to chemical and physical processes, biological treatments are environmental friendly but they have to take into account the biodegradation difficulties associated both with the high salinity, that could increase the osmotic pressure leading to cell death $[6,7,24,25]$ and recalcitrant/toxic compounds which could inhibit the metabolism of microorganisms $[1,26]$. Activated sludge is the usual method for treating wastewater. Freire et al. (2001) [27] found that salinity did not have significant effect on chemical oxygen demand (COD) removal of mixed wastewater, only recalcitrance of organic compounds affected biological treatment. However, when salinity increased to $100,000 \mathrm{mg} / \mathrm{L}$, the biodegradation rate fell dramatically because high concentration of sodium chloride causes environmental stress, microbial lysing effects, and promotes loss of biomass [28]. The principal mechanism of hydrocarbon removal by microorganisms in biological treatment is biodegradation by microorganisms with bio-flocculation. Biodegradation of less complex oil components, e.g., normal alkanes is easier than of complex and large molecules. Less biodegradable oil molecules attached to microorganisms will remain in the aeration tank. So, these components are removed along with sludge in excess-sludge removal processes [1]. To improve biological treatment of effluent, membranes bioreactors (MBR) can be used. As well known in literature, membranes are used in various applications, from desalination of sea water to treatment of wastewater from the food, leather and oil industry [29]. MBRs may ensure high-quality effluent, small footprint and low sludge production rates [30], so suggesting the treatment of saline waters contaminated by recalcitrant compounds, such as petroleum hydrocarbons [31]. Fouling of membranes is the first drawback of MBRs and it is the deposition of substances on the membrane surface, like oil droplets or solid particles. Dickhout et al. (2017) [2] proposed a fouling mechanism for oily wastewater and they found that oil droplets are coalescing on the membrane surface, forming a continuous oil layer on the surface, different from a traditional cake layer made of separate particles. In this context, membrane materials are relevant for the treatment of oily wastewater and, until now, ceramic membranes are favored over polymeric membranes because of their superior mechanical stability. In addition, high concentrations of salinity and petroleum hydrocarbons can exert significant stress towards the biomass, resulting in an overall worsening of mixed liquor characteristics in terms of viscosity, amount of filamentous bacteria, extracellular polymeric substances (EPSs) and soluble microbial products(SMPs), producing substantial membrane fouling [32-34]. Recently, MBRs are used together with biofilm such as moving bed biofilm reactors (MBBRs) to promote biofilm growth on mobile carriers and to enhance the overall biological removal efficiencies performances [35]. The combination between MBR and MBBR systems is usually referred to as moving bed membrane bioreactor (MB-MBR) $[6,7,36]$ and it has been proved to develop specialized bacterial consortium inside the bioreactor [37]. Based on the above, any biological system needs to be previously adapted to saline oily wastewater to obtain appreciable results.

The previously described chemical, physical and biological treatments, may be used as stand-alone treatments or in chain, in order to optimize and to strengthen the overall removal efficiencies of recalcitrant compounds like those contained in oily slop wastewater. At this purpose, physical adsorption on PAC or GAC was already studied as pre-treatment step prior to membrane 
filtration [38,39]. PAC may be used in combination with membrane filtration in the same tank proving its beneficial effect on membrane fouling [40], while GAC pre-treatment resulted in a removal efficiency of $80-90 \%$ of dissolved organic matter from MBR effluents, so stabilizing membrane permeability and increasing permeate quality [41]. Kose-Mutlu et al. (2017) [38] found that GAC was better than PAC owing to the high organic matter removal as pre-treatment process.

Bearing in mind the above, this study is aimed to offer an overview about the potential treatments of slop wastewater, focusing on chemical, physical and biological treatments. In particular, a slop wastewater sampled from the same oil coastal deposit, was treated with coagulation-flocculation (chemical), adsorption on GAC (physical) and MBR/MB-MBR (biological) processes, as stand-alone treatments. Based on the results of each independent process, the authors hypothesized different scenarios of treatment chains depending on the load of recalcitrant contaminants, such as hydrocarbons, contained in slop wastewater. Therefore, the ultimate goal of this work was to provide a know-how instrument for harbour authorities, private companies and for the scientific community, that will have to manage this kind of industrial wastewater. In the case, this study has been framed within a research project based on the definition of a proposal of train-treatment for shipboard slop wastewater.

\section{Materials and Methods}

\subsection{Analytical Methods}

All measurements discussed in the note were carried out in accordance with the standard methods for the examination of treated water and wastewater [42].

Due to high salinity, the COD measurements provide an uncertain and unreliable estimation. For this reason, the standard protocol of COD analysis was slightly modified. More specifically, the measurement was made on the basis of the standard methods, but with appropriate modifications due to the high presence of chlorides: the sample was diluted with pure water $(1: 10)$ and the amount of mercury sulphate dosed was proportional to the chlorides concentration in the sample.

Total organic carbon (TOC) was measured by means of thermos-catalytic oxidation with a high-temperature TOC- $\mathrm{V}_{\mathrm{CSH}}$ analyser. Even if TOC analysis is not mandatory, they were performed in parallel to support the interpretations of the COD tests, since it is a good indicator for the evaluation of organic compounds removal.

Finally, TPHs were analysed by injecting $1 \mu \mathrm{L}$ of headspace/liquid sample to a Gas Chromatograph (GC-Agilent $6890 \mathrm{~N}^{\circledR}$, Milan, Italy), equipped with a capillary column (DB-1) of $30 \mathrm{~m}$ in length, and a Flame Ionization Detector (FID), after liquid-liquid extraction of the TPH from the samples by means of hexane, according to [43]. Both the injector and detector temperatures were kept at $340{ }^{\circ} \mathrm{C}$.

All analysis were performed in triplicates.

\subsection{The Industrial Shipboard Wastewater: Slop}

Slop wastewater was sampled from a floating tank of an oil costal deposit in the Augusta harbor (Sicily-Italy). The slops were derived from the washing of tanks containing crude oil or refined product. A preliminary and simple gravity separation (with a hydraulic retention time of $2 \mathrm{~h}$ ) was performed in a proper de-oiler to reduce the high floating oil content. Subsequently, approximately $300 \mathrm{~L}$ of the clarified wastewater was refrigerated at $4{ }^{\circ} \mathrm{C}$ to inhibit any biological activity.

Characterization of slop wastewater is not easy due to its heterogeneity and high amount of emulsified oils. Slop was analyzed without dilution, considering the liquid matrix as a "complex mixture" [44]. Table 1 reports the main characterization of slop wastewater collected from "Augusta bay".

As industrial wastewater, slop after gravity de-oiling is mainly characterized by high COD, next to $1.3 \mathrm{~g} \cdot \mathrm{L}^{-1}$, of which only about $30 \%$ constitutes the total organic carbon. Moreover, only about $30 \%$ of TOC is represented by hydrocarbons. Given the discharge limits of $125 \mathrm{mg} \cdot \mathrm{L}^{-1}$ for COD and 5 
$\mathrm{mg} \cdot \mathrm{L}^{-1}$ for TPH imposed respectively by Italian legislative decree 152/2006 and MARPOL 73/78, removal efficiencies of more than $90 \%$ are required. Furthermore, since slop wastewater is seawater contaminated by hydrocarbons, it is characterized by high salinity next to $39 \mathrm{gNaCl} \cdot \mathrm{L}^{-1}$. At this purpose, although salinity is not a form of pollution, it could be an obstacle for biological treatment when halotolerant or halophilic bacteria are not employed.

Regarding to metals content, there were not measured relevant concentration of hazardous metals. Moreover, the preliminary de-oiling, significantly reduced the turbidity of the sample (data not shown).

In order to focusing on the main pollutants of slop represented by hydrocarbons, a representative chromatogram of the influent is reported in Figure 2. As can be seen, the overall speciation of TPH (C10-C40) is mainly comprised in the Diesel Range Organics (DRO) (C10-C28) [43].

Table 1. Main characteristics of the industrial slop wastewater after de-oiling.

\begin{tabular}{cccc}
\hline Parameter & Symbol & Units & Value \\
\hline Chemical Oxygen demand & $\mathrm{COD}$ & $\mathrm{mg} \cdot \mathrm{L}^{-1}$ & $1.327 \pm 328$ \\
Total Organic Carbon & $\mathrm{TOC}$ & $\mathrm{mg} \cdot \mathrm{L}^{-1}$ & $428 \pm 62$ \\
Total Petroleum Hydrocarbons & $\mathrm{TPH}$ & $\mathrm{mg} \cdot \mathrm{L}^{-1}$ & $135 \pm 38$ \\
Sodium Chloride & $\mathrm{NaCl}$ & $\mathrm{g} \cdot \mathrm{L}^{-1}$ & $38.67 \pm 0.19$ \\
Conductivity & - & $\mathrm{mS} \cdot \mathrm{cm}^{-1}$ & $48 \pm 2$ \\
pH & - & - & $7.78 \pm 0.62$ \\
Total Suspended Solids & & $\mathrm{mg} \cdot \mathrm{L}^{-1}$ & $352 \pm 84$ \\
Metals & & & \\
Aluminum & $\mathrm{Al}$ & $\mathrm{mg} \cdot \mathrm{L}^{-1}$ & $<0.005$ \\
Arsenic & $\mathrm{As}$ & $\mathrm{mg} \cdot \mathrm{L}^{-1}$ & $<0.001$ \\
Boron & $\mathrm{Bo}$ & $\mathrm{mg} \cdot \mathrm{L}^{-1}$ & 5.02 \\
Cadmium & $\mathrm{Cd}$ & $\mathrm{mg} \cdot \mathrm{L}^{-1}$ & $<0.001$ \\
Chrome & $\mathrm{Cr}$ & $\mathrm{mg} \cdot \mathrm{L}^{-1}$ & $<0.005$ \\
Iron & $\mathrm{Fe}$ & $\mathrm{mg} \cdot \mathrm{L}^{-1}$ & 1.18 \\
Manganese & $\mathrm{Mn}$ & $\mathrm{mg} \cdot \mathrm{L}^{-1}$ & $<0.005$ \\
Nickel & $\mathrm{Ni}$ & $\mathrm{mg} \cdot \mathrm{L}^{-1}$ & $<0.005$ \\
Copper & $\mathrm{Cu}$ & $\mathrm{mg} \cdot \mathrm{L}^{-1}$ & $<0.005$ \\
Selenium & $\mathrm{Se}$ & $\mathrm{mg} \cdot \mathrm{L}^{-1}$ & $<0.005$ \\
Lead & $\mathrm{Pb}$ & $\mathrm{mg} \cdot \mathrm{L}^{-1}$ & $<0.005$ \\
Zinc & $\mathrm{Zn}$ & $\mathrm{mg} \cdot \mathrm{L}^{-1}$ & $<0.005$ \\
\hline
\end{tabular}

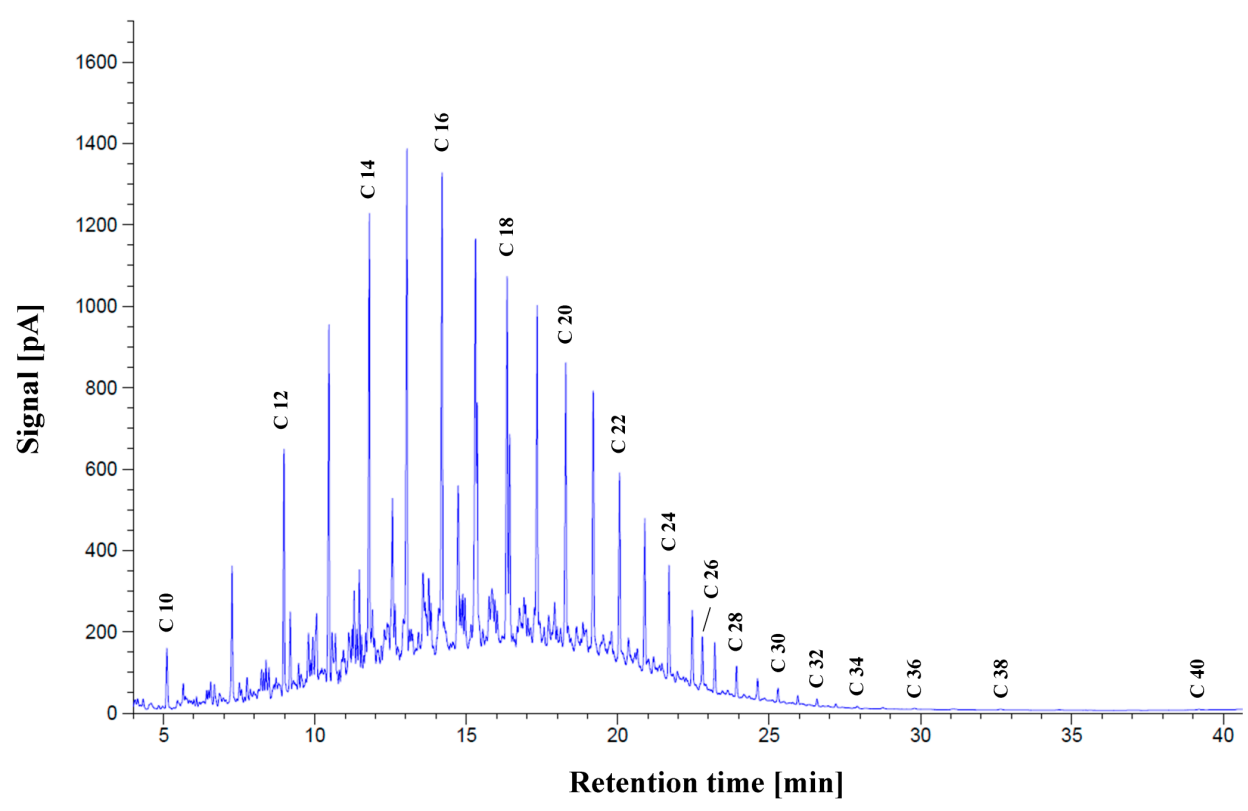

Figure 2. Chromatogram of TPH of de-oiled slop after GC-FID analysis. 


\subsection{Bench Scale Processes}

All the experimental studies were carried out at the laboratory of sanitary and environmental engineering of Kore University of Enna (Sicily).

\subsubsection{Batch Test for Analysis of Chemical Treatment}

The study of chemical treatment of slops was executed by coagulation and flocculation processes. In a previous research [5], multiples jar tests were performed in order to identify the appropriate type of coagulant between the aluminum sulphate $\left(\mathrm{Al}_{2}\left(\mathrm{SO}_{4}\right)_{3}\right)$ and ferric chloride $\left(\mathrm{FeCl}_{3}\right)$. Practically, after coagulation/flocculation, the suspension was poured into a graduated cylinder for sedimentation. Supernatant samples were taken beneath the liquid surface for turbidity measurements. The jar tests were run at $200 \mathrm{rpm}$ for $1 \mathrm{~min}$, during the coagulation phase, and $30 \mathrm{rpm}$ for $20 \mathrm{~min}$, during the flocculation phase, and final settling for $180 \mathrm{~min}$. In the present study, only the best coagulant type and dose were taken into account for the analysis of results. In particular, here the best configuration has been analysed with a dose of $70 \mathrm{mg} \cdot \mathrm{L}^{-1}$ of $\mathrm{Al}_{2}\left(\mathrm{SO}_{4}\right)_{3}$ coupled with $2.5-5.0 \mathrm{mg} \cdot \mathrm{L}^{-1}$ of anionic flocculant. The performance has been presented in terms of percentage of pollutant removal from raw water (slops), after the operations of coagulation and/or coagulation-flocculation, according to Equation (1):

$$
\eta=\frac{X_{\text {Slop }}-X_{\text {Treated }}}{X_{\text {Slop }}} \times 100,[\%]
$$

where: $X_{\text {Slop }}$ and $X_{\text {Treated }}$ are the concentration of pollutant (COD, TPH, TOC) in the slop and in the treated water, respectively.

\subsubsection{Batch and Dynamic Test for Physical Treatment}

The physical treatment, tested in this study, was the adsorption on granular activated carbon (GAC). Before to carry out the batch and continuous tests, GAC was treated according to the standard methods [45]. The batch tests were carried-out in order to define the "isotherm curves" and the main "Kinetics features" (data not shown).

The adsorption isotherms for both different adsorbents were determined, considering the COD, TOC and TPH concentration with the original value found in the real slops. As discussed above, these parameters are generally used to characterize the overall organic pollution in oily wastewater. The volume of $100 \mathrm{~mL}$ of adsorbate required by the analytical protocols is consistent with the standard implementation of the test and its repeatability. Only in the case of the TPH analysis, in agreement with the "minimum sample volume" reported in the standard method, a volume of $500 \mathrm{~mL}$ of the sample was tested [45]. Data from the batch adsorption experiments were fit according to Freundlich isotherm models written in Equation (2):

$$
\mathrm{q}_{\mathrm{e}}=\mathrm{K}_{\mathrm{F}} \mathrm{C}_{\mathrm{e}}^{1 / \mathrm{n}}
$$

where $\mathrm{q}_{\mathrm{e}}$ is the mass of adsorbate per gram of sorbent $\left(\mathrm{mg} \cdot \mathrm{g}^{-1}\right), \mathrm{C}_{\mathrm{e}}$ is the concentration of adsorbate at the liquid-phase equilibrium $\left(\mathrm{mg} \cdot \mathrm{L}^{-1}\right) . \mathrm{K}_{\mathrm{fF}}$ and $1 / \mathrm{n}$ are the empirical Freundlich constants which indicate absorption capacity and adsorption intensity, respectively.

The amount of granular activated carbon analyzed in the present study was equal to $20 \mathrm{~g} \cdot \mathrm{L}^{-1}$. In order to determine the amount of COD, TOC and TPH remaining in solution, different samples (one for each analyzed pollutant) of the mixture were taken at appropriate intervals, filtered, and analyzed. Specifically, the experiments to determine the equilibrium time were performed with the contact time between adsorbent and adsorbate in the range of $0-24 \mathrm{~h}$, with an initial concentration of single pollutant practically equal to original concentration in the slops. The removal percentage ( $\eta$ ) of COD, TOC or TPH was calculated from the following general Equation (3): 


$$
\eta=\frac{C_{0}-C_{t}}{C_{0}} \times 100,(\%)
$$

where $C_{0}$ and $C_{t}$ are the initial concentration and the concentration at the time $t$ of pollutant $\left(\mathrm{mg} \cdot \mathrm{L}^{-1}\right)$, respectively.

\subsubsection{Bench Scale Application for Biological Treatment}

Regarding the biological treatment, two technologies are proposed: a membrane bioreactor (MBR) and a Moving Bed-Membrane Bioreactor (MB-MBR) characterized by the presence of soft polyurethane sponges as carrier material for biofilm growth, details can be found in [6,7]. The feeding wastewater was stored in a $150 \mathrm{~L}$ tank, equipped with a mechanical mixer, from which it was fed to the pilot plants. Both plants were characterized by bioreactors of equivalent volume (15 L each) and were equipped with an ultrafiltration (UF) hollow fiber membrane module. To limit the fouling extent due to superficial cake deposition, each membrane was periodically backwashed (every $4 \mathrm{~min}$ for a period of $1 \mathrm{~min}$ ) by pumping a fraction of permeate back through the membrane. The outlet permeate from each pilot was stored in a separate "permeate tank". The bioreactor of the MB-MBR line was filled with polyurethane sponge carriers with a 30\% filling fraction. The two bench scale plants were inoculated with activated sludge collected from the Enna municipal wastewater treatment plant. The reactors operated in a continuous configuration at room temperature, with an hydraulic retention time (HRT) in the range $12-15 \mathrm{~h}$, and with a complete sludge retention time (SRT) strategy in order to promote biomass adaptation to saline conditions and to recalcitrant substrates [36]. However, the biomass extracted from the system was only the necessary amount for analysis. The biomass acclimation was carried out together with slop dosage in order to favor a step-wise increase of salinity and hydrocarbons and to avoid metabolic shocks and inhibition of bacteria [6,7]. This acclimation technique is always recommended when treating substrates with refractory compounds. Moreover, since preliminary results showed that MB-MBR with 50\% volume of slop dosage was better than MBR with $50 \%$ volume of slop dosage [6], the authors decided to prosecute and to analyse the results of $100 \%$ volume of slop dosage only for the MB-MBR process [7]. In addition, the biological removal efficiencies both in the MBR and MB-MBR systems were evaluated by analyzing samples of mixed liquor, before physical filtration with ultrafiltration membrane.

\section{Results and Discussion}

The three proposed treatment schemes were compared in terms of COD, TOC and TPH removal, thinking and testing each process as a standalone treatment. However, from the obtained results it is possible to contemplate a possible disposition of the analyzed processes as a treatment chain in order to provide the best removal efficiencies, coupled to a suitable and simple management action.

\subsection{COD Removal}

Figure 3 shows a comparison in terms of COD removal efficiency between the proposed treatments. In this context, as observed above, it is important underline that the COD data are affected by high uncertainty and poor reproducibility because of high salinity and the interference of chlorides on the measurement.

Looking at the biological treatment, the membrane bioreactors showed a better behaviour of the MB-MBR compared to the MBR one. This result was likely related to the higher amount of total biomass retained inside the system, both suspended and attached. Furthermore, a gradual increase of COD removal efficiency next to $90 \%$ was observed, even with a $100 \%$ volume of slop fed to the reactor. This result revealed that, after an initial biological shock of biomass due to the recalcitrant compounds of the influent, microorganisms could adapt to salt and hydrocarbons and grow above the less biodegradable substrate. 
On the other hand, concerning chemical treatment with coagulation/flocculation, the removal efficiency of COD resulting from $\mathrm{Al}_{2}\left(\mathrm{SO}_{4}\right)_{3}$ addition was found at $>70 \%$ using a coagulant dose of $70 \mathrm{mg} \cdot \mathrm{L}^{-1}$ without depending on the anionic flocculant dosage. The main removal principle at low alum concentrations was found to be adsorption and charge neutralisation.

Finally, with physical GAC treatment the COD was removed as a function of the utilized mass of activated carbon $\left(20 \mathrm{mg} \cdot \mathrm{L}^{-1}\right)$, related to the increase of the contact surface, rather than to the adsorbent affinity to the organic matter. Indeed, the COD includes all the chemically oxidable forms, both organics and inorganics and activated carbon mainly acted towards the organic compounds. For this reason, the removal efficiency of COD by GAC was not higher than $70 \%$.

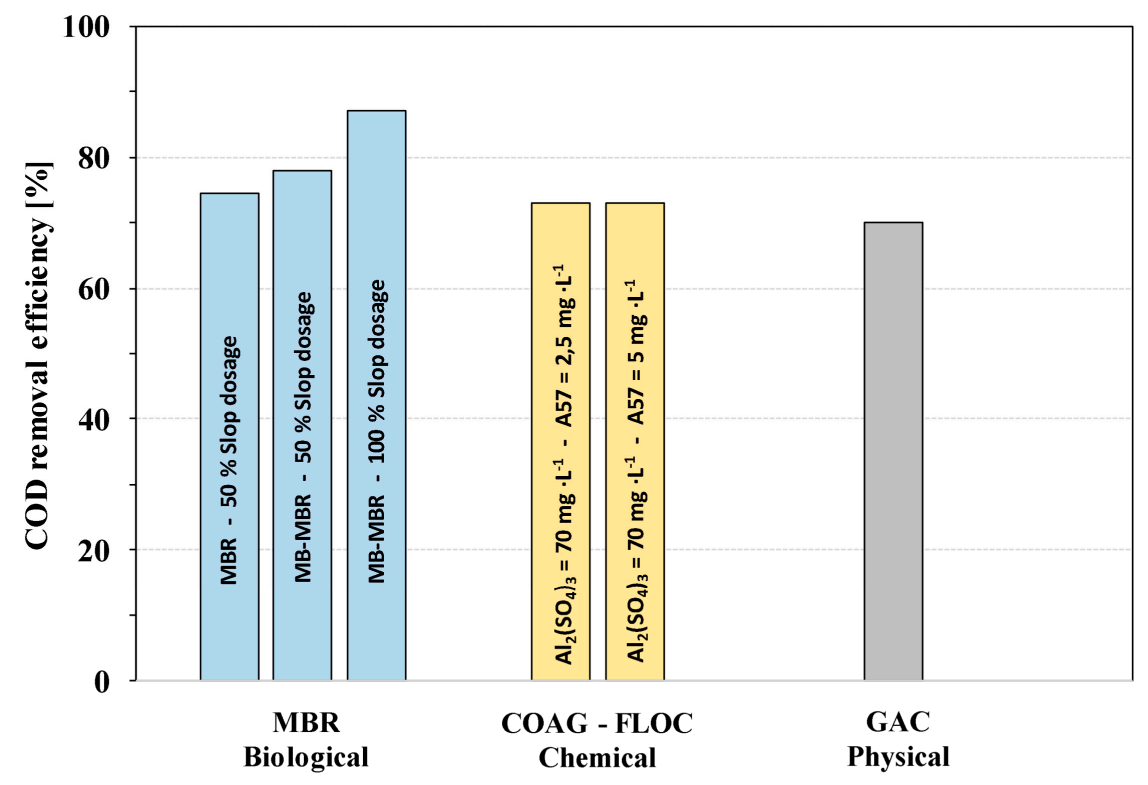

Figure 3. COD removal efficiency of the biological (MBR), chemical (coagulation-flocculation) and Physical (GAC) treatments of slop.

\subsection{TOC Removal}

As shown in Figure 4, the best result in terms of TOC removal efficiency of slop was obtained with GAC system, obtaining values of about $90 \%$ for a GAC dosage of $20 \mathrm{mg} \cdot \mathrm{L}^{-1}$. As discussed previously, the activated carbon acts in a more efficient way towards the organic matter because of the higher affinity between the organic adsorbent and the dissolved organic carbon.

On the other hand, coagulation-flocculation treatment revealed the lowest TOC removal efficiencies, next to $50 \%$, because this treatment is properly adapted to mainly remove colloidal solids from water favouring the coalescence into particles of higher dimensions. So, since TOC is representative of dissolved organic matter, this treatment didn't offer high removal efficiency for this parameter. However, it could be used as pre-treatment in order to reduce the influent concentration for the following processes.

No significant difference between MBR and MB-MBR removal efficiency of TOC was observed when $50 \%$ volume of slop was dosed in the influent. In general, more than $95 \%$ of TOC was removed while, when slop dosage was increased to $100 \%$, a slight decrease of TOC removal efficiency down to $87 \%$ was registered. When $50 \%$ volume of slop was dosed, the achieved performance was higher likely due to the fact that slop was mixed with a synthetic solution with readily biodegradable sodium acetate as carbon source. It should be stressed that sodium acetate was temporary added to feeding in order to favour a gradual acclimation of biomass to the recalcitrant carbon source of slop. This probably helped the biodegradation of dissolved total organic carbon also of the recalcitrant fraction, probably due to co-metabolism of microorganisms. Bacteria may have biodegraded the more complex 
molecules of recalcitrant compounds, by metabolizing another substrate more readily biodegradable like sodium acetate. On the other hand, when only slop was fed to the reactor, the only carbon source was represented by hydrocarbons and other kind of recalcitrant organic matter of the industrial wastewater, more difficult to biodegrade. So, the result of $87 \%$ of TOC removal efficiency, confirmed the acclimation of biomass to the organic matter of the recalcitrant substrate.

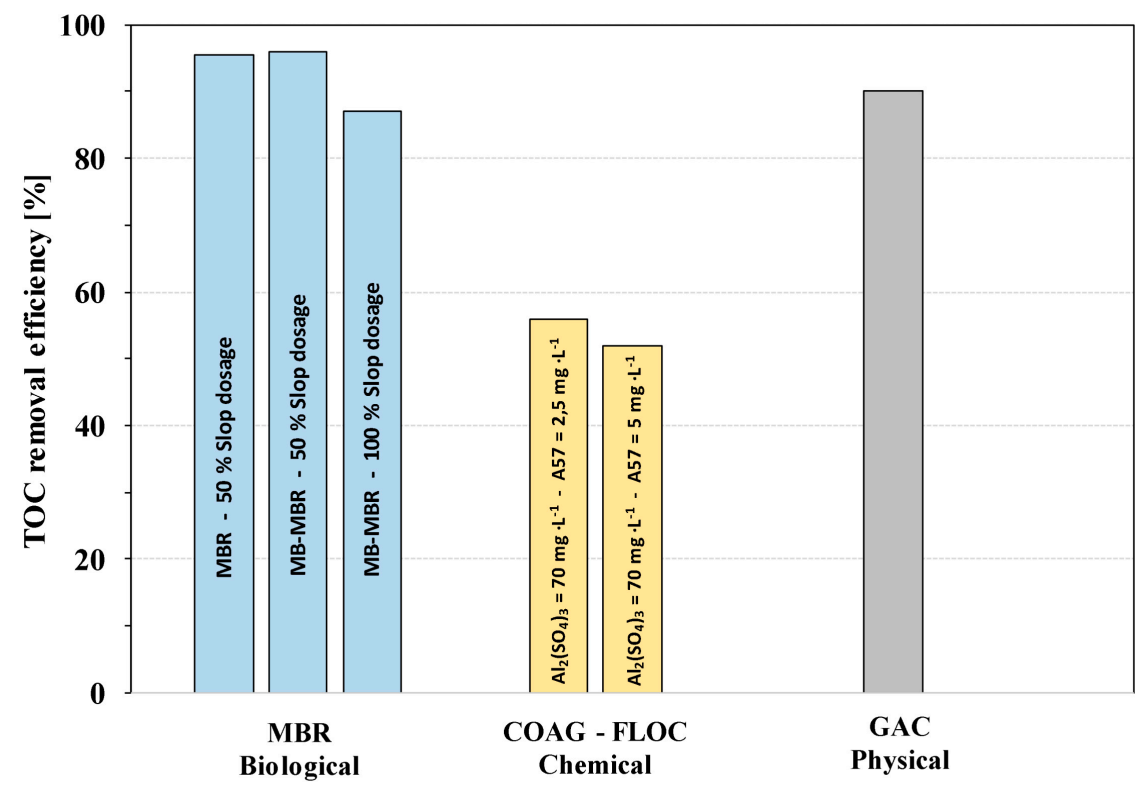

Figure 4. TOC removal efficiency of the biological (MBR), chemical (coagulation-flocculation) and Physical (GAC) treatments of slop.

\subsection{TPH Removal}

The parameter of main interest concerning slop wastewater treatment is represented by TPH, given its high environmental impact and its recalcitrant nature. So, by comparing the three proposed treatments (Figure 5), it is possible to note that physical GAC treatment offered the best performances with about $85 \%$ of removal efficiency. This result confirmed the suitability of activated carbon for the removal of organic substances. Since hydrocarbons are organic compounds, they have a great affinity with GAC, and a great amount of TPH were adsorbed on and into granules of activated carbon. This could imply a progressive saturation during time of GAC column and the need to proceed with the substitution or re-generation of the bed by means of physical (heating) or biological methods (by placing acclimated biomass for a fixed contact time, inside the bed of saturated GAC).

Regarding to the chemical treatment by means of coagulation-flocculation, a low value of removal efficiency, near to $55 \%$, was registered. This was probably due to the presence of emulsified hydrocarbons that were not affected by the coagulant and flocculant action, so remaining in liquid phase.

The real challenge in the removal of TPH is represented by biological treatment. Also in this case, the MB-MBR system revealed a higher removal efficiency of TPH compared to MBR. This was mainly due to the additional biological effect of attached biomass on mobile carriers in the MB-MBR system. However, when $50 \%$ volume of slop was fed to the system, no more than $47 \%$ of removal efficiency was obtained, probably due to a partial acclimation of bacteria to hydrocarbons. On the other hand, by feeding the system with $100 \%$ volume of slop, the increase of removal efficiency (70\%) suggested a higher acclimation of bacteria to TPH when hydrocarbons were the only carbon source. 


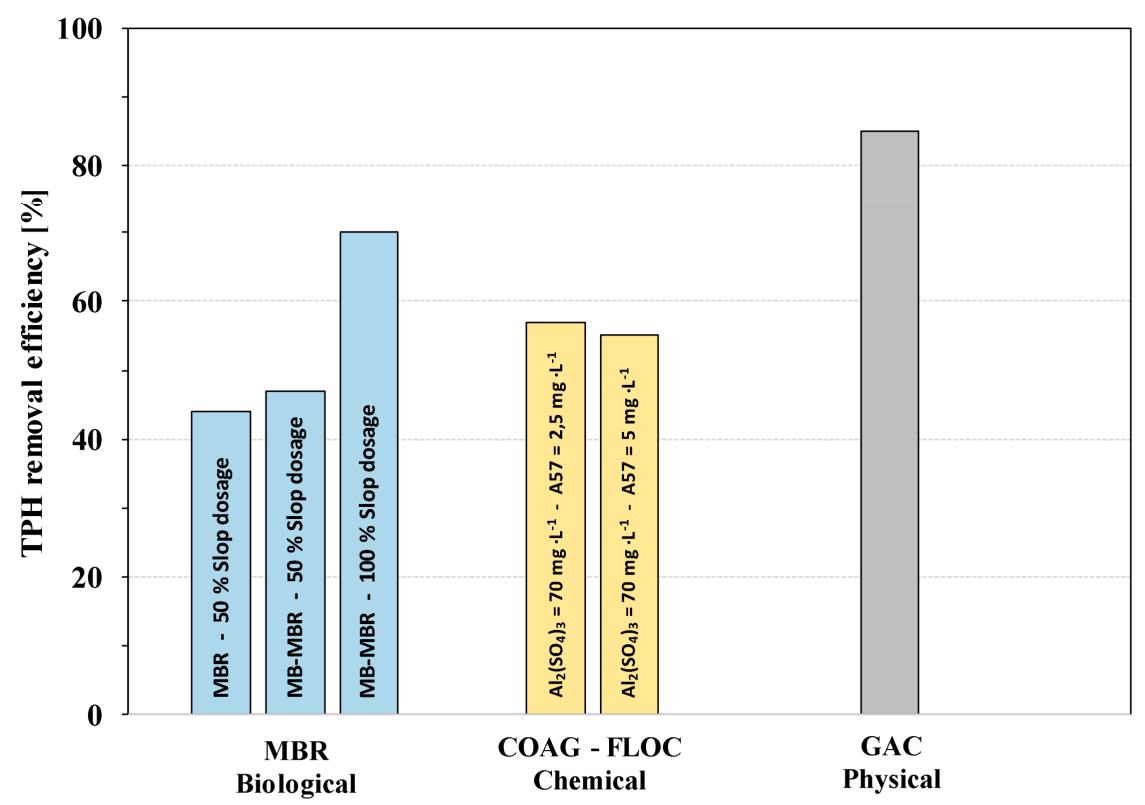

Figure 5. TPH removal efficiency of the biological (MBR), chemical (coagulation-flocculation) and Physical (GAC) treatments of slop.

\subsection{Discussion about Treatment Chains Proposals}

All the obtained results were discussed by considering each process as the sole treatment of slop wastewater. However, depending on the characteristic of wastewater and the peculiarity of each technology, a specific treatment chain could be envisaged in order to meet the MARPOL 73/78 law discharge limits.

Referring on TPH as contaminant of interest, when there is the need to treat low TPH load industrial wastewater (TPH $<30 \mathrm{mgTPH} \cdot \mathrm{L}^{-1}$ ), only biological MBR or MB-MBR processes could be applied with a preliminary phase of acclimation of biomass to recalcitrant hydrocarbon substrates and/or to salinity. In this case, a preliminary coagulation-flocculation step could be used in order to limit the biological stress of suspended biomass (and indirectly the sludge production).

On the other hand, the treatment of a "medium TPH load" industrial wastewater $\left(30<\mathrm{mgTPH} \cdot \mathrm{L}^{-1}<150\right)$ is not recommended applying biological treatment only, since the high concentrations of contaminants could inhibit the metabolic activity of biomass. So, a high efficiency preliminary treatment by GAC, before the biological process, could be foreseen. Indeed, as discussed previously, granular activated carbon technology offered a high affinity of the organic adsorbent carbon towards the organic hydrocarbons in liquid phase of wastewater, resulting in a high preliminary removal of TPH before the biological treatment. Also in this case, coagulation-flocculation is an option in order to mainly remove colloidal suspensions, achieving better removal efficiencies.

Finally, for the treatment of "high TPH load" industrial wastewater (TPH > $150 \mathrm{mgTPH} \cdot \mathrm{L}^{-1}$ ) all the physical, chemical and biological steps are necessary to obtain the required removal efficiencies. In similar conditions, if the biological treatment is the only option, the dilution of feeding waters with municipal wastewater could be necessary thus requiring very large bioreactors in order to decrease the F/M ratio. Therefore, a viable possibility to face this operational problem is to design different processes to be placed in series in the same treatment chain. Each process has to be designed in order to mainly remove a specific contaminant. So, based on the above discussed results, it could be possible to remove a high amount of hydrocarbons and organic matter with a preliminary GAC treatment. In this case, also an initial coagulation-flocculation step is recommended in order to increase the overall removal efficiencies. At this purpose, since the discussed results of chemical treatment are referred to batch tests, it could be of relevant interest to analyse the possibility to design a continuous 
coagulation-flocculation treatment of slop. Finally, the MBR or MB-MBR processes will be able to remove the residual lower concentration of TPH and other organic substances. Table 2 reports different proposals of treatment chains hypothesized by selecting TPH as contaminant of interest, given its high recalcitrant nature.

Table 2. Treatment chain proposal depending on the influent concentration of TPH (in parentheses, suggested proposals are reported).

\begin{tabular}{ccccc}
\hline Influent Characteristics & & Treatment Chain & Law Limit \\
& Physical & Chemical & Biological \\
(MARPOL 73/78) [4]
\end{tabular}

The proposed treatment schemes reported in Table 2 take into account only the removal efficiencies of each technologies, not considering any economic evaluation since it was not the main objective of the work. However, it is should be stressed that, if economic criteria are to be considered, the scenarios of treatment proposals could appear completely different from those proposed. In particular, a first cost item is represented by the consumption/saturation of GAC that needs to be replaced or regenerated. Replacement and disposal of activated carbon is the most expensive way, while bioregeneration obtained by mixing adapted bacteria with saturated GAC, represents a valid alternative to regenerate exhausted carbon and it is less expensive than thermal regeneration process. However, despite of the recovery of a significant adsorption capacity of GAC, the bioregeneration process does not ensure a full regeneration of activated carbon [21]. Moreover, the largest cost item for chemical treatments is the purchase of chemical reagents, such as coagulants and flocculants, those must be continuously dosed within the process. Regarding to MBR systems, the main costs are represented by the membrane itself (capital costs) and by operational procedures to limit the fouling (operational costs), such as physical and chemical cleaning [30]. However, based on this preliminary study, further research is needed to really demonstrate the proposed schemes as a real treatment chain, both in lab or pilot scale, and to consider the economic impact of the whole process.

\section{Conclusions}

This work is focused on the issue of treatment of shipboard slops contaminated by hydrocarbons, produced by the activity of washing of oil tankers. As industrial wastewater, slops are characterized by recalcitrant compounds like TPHs, and nowadays its treatment is a challenge and mandatory for harbor authorities in order to meet the current MARPOL 73/78 discharge limits. Three kinds of treatments, physical, chemical and biological, were analyzed in terms of removal efficiencies of COD, TOC and TPH as standalone process. GAC treatment offered the highest removal efficiencies in terms of TPH $(\approx 85 \%)$, since the activated carbons are designed to remove organic matter, and it is conceived for medium-high TPH load influents, as preliminary treatment. In general, coagulation-flocculation and GAC-adsorption treatments are known to remove colloidal suspensions, so it could be optionally used for low and medium TPH load influents in order to obtain better removal efficiencies. On the other hand, their use is strongly recommended for high TPH load influents. Biological treatments are always foreseen in each treatment chain, as the last step of treatment to remove the residual concentrations of pollutants. In this study, the MB-MBR process registered higher removal efficiency than a traditional MBR tanks to the additional biological action of attached biomass on the mobile 
carriers. A step-wise increase of salinity and hydrocarbons is recommended to enhance the acclimation of biomass to industrial real slop wastewater treatment.

Acknowledgments: This work was funded by the National Operational Program for Research and Competitiveness 2007-2013. Project "SIBSAC—An integrated system for sediments remediation and high salinity marine wastewaters treatment".

Author Contributions: Riccardo Campo conceived and designed the experiments concerning Biological Treatment; Maria Gabriella Giustra conceived and designed the experiments concerning Physical and Chemical-Physical Treatment; Gabriele Freni and Mauro De Marchis partly wrote this paper, controlled English form and edited figures; Gaetano Di Bella, conceived the study, supervised the work and partly wrote this paper.

Conflicts of Interest: The authors declare no conflict of interest.

\section{References}

1. Fakhru'l-Razi, A.; Pendashteh, A.; Abdullah, L.C.; Biak, D.R.A.; Madaeni, S.S.; Abidin, Z.Z. Review of technologies for oil and gas produced water treatment. J. Hazard. Mater. 2009, 170, 530-551. [CrossRef] [PubMed]

2. Dickhout, J.M.; Moreno, J.; Biesheuvel, P.M.; Boels, L.; Lammertink, R.G.H.; de Vos, W.M. Produced water treatment by membranes: A review from a colloidal perspective. J. Colloid Interface Sci. 2017, 487, 523-534. [CrossRef] [PubMed]

3. Sheng, J.J. Modern Chemical Enhanced Oil Recovery; Elsevier: Amsterdam, The Netherlands, 2011.

4. International Maritime Organization. MARPOL: Articles, Protocols, Annexes, Unified Interpretations of the International Convention for the Prevention of Pollution from Ships, 1973, as Modified by the Protocol of 1978 Relating Thereto; International Association of Classification Societies (IACS): London, UK, 2006.

5. Di Bella, G.; Giustra, M.G.; Freni, G. Optimisation of coagulation/flocculation for pre-treatment of high strength and saline wastewater: Performance analysis with different coagulant doses. Chem. Eng. J. 2014, 254, 283-292. [CrossRef]

6. Di Bella, G.; Di Prima, N.; Di Trapani, D.; Freni, G.; Giustra, M.G.; Torregrossa, M.; Viviani, G. Performance of membrane bioreactor (MBR) systems for the treatment of shipboard slops: Assessment of hydrocarbon biodegradation and biomass activity under salinity variation. J. Hazard. Mater. 2015, 300, 765-778. [CrossRef] [PubMed]

7. Campo, R.; Di Prima, N.; Gabriella Giustra, M.; Freni, G.; Di Bella, G. Performance of a moving bed-membrane bioreactor treating saline wastewater contaminated by hydrocarbons from washing of oil tankers. Desalin. Water Treat. 2016, 57. [CrossRef]

8. Fakhru'l-Razi, A.; Pendashteh, A.; Abidin, Z.Z.; Abdullah, L.C.; Biak, D.R.A.; Madaeni, S.S. Application of membrane-coupled sequencing batch reactor for oilfield produced water recycle and beneficial re-use. Bioresour. Technol. 2010, 101, 6942-6949. [CrossRef] [PubMed]

9. Jain, P.; Sharma, M.; Dureja, P.; Sarma, P.M.; Lal, B. Bioelectrochemical approaches for removal of sulfate, hydrocarbon and salinity from produced water. Chemosphere 2017, 166, 96-108. [CrossRef] [PubMed]

10. Bell, E.A.; Poynor, T.E.; Newhart, K.B.; Regnery, J.; Coday, B.D.; Cath, T.Y. Produced water treatment using forward osmosis membranes: Evaluation of extended-time performance and fouling. J. Memb. Sci. 2017, 525, 77-88. [CrossRef]

11. Bonfá, M.R.L.; Grossman, M.J.; Mellado, E.; Durrant, L.R. Biodegradation of aromatic hydrocarbons by Haloarchaea and their use for the reduction of the chemical oxygen demand of hypersaline petroleum produced water. Chemosphere 2011, 84, 1671-1676. [CrossRef] [PubMed]

12. Ebrahimi, M.; Ashaghi, K.S.; Engel, L.; Willershausen, D.; Mund, P.; Bolduan, P.; Czermak, P. Characterization and application of different ceramic membranes for the oil-field produced water treatment. Desalination 2009, 245, 533-540. [CrossRef]

13. Ebrahimi, M.; Willershausen, D.; Ashaghi, K.S.; Engel, L.; Placido, L.; Mund, P.; Bolduan, P.; Czermak, P. Investigations on the use of different ceramic membranes for efficient oil-field produced water treatment. Desalination 2010, 250, 991-996. [CrossRef]

14. Mondal, S.; Wickramasinghe, S.R. Produced water treatment by nanofiltration and reverse osmosis membranes. J. Memb. Sci. 2008, 322, 162-170. [CrossRef] 
15. Motta, A.; Borges, C.; Esquerre, K.; Kiperstok, A. Oil Produced Water treatment for oil removal by an integration of coalescer bed and microfiltration membrane processes. J. Memb. Sci. 2014, 469, 371-378. [CrossRef]

16. Nghiem, L.D.; Elters, C.; Simon, A.; Tatsuya, T.; Price, W. Coal seam gas produced water treatment by ultrafiltration, reverse osmosis and multi-effect distillation: A pilot study. Sep. Purif. Technol. 2015, 146, 94-100. [CrossRef]

17. Wandera, D.; Himstedt, H.H.; Marroquin, M.; Wickramasinghe, S.R.; Husson, S.M. Modification of ultrafiltration membranes with block copolymer nanolayers for produced water treatment: The roles of polymer chain density and polymerization time on performance. J. Memb. Sci. 2012, 403-404, 250-260. [CrossRef]

18. Zhou, F.S.; Zhao, M.F.; Ni, W.X.; Dang, Y.S.; Pu, C.S.; Lu, F.J. Inorganic polymeric flocculent FMA for purifying oilfield produced water: Preparation and uses. Oilfield Chem. 2000, 17, 256-259.

19. Houcine, M. Solution for Heavy Metals Decontamination in Produced Water/Case Study in Southern Tunisia. In Proceedings of the SPE International Conference on Health, Safety and Environment in Oil and Gas Exploration and Production, Kuala Lumpur, Malaysia, 20-22 March 2002; Society of Petroleum Engineers: Richardson, TX, USA, 2002.

20. Hansen, B.R. Review of potential, technologies for the removal of dissolved components from produced water. Chem. Eng. Res. Des. 1994, 72, 176-188.

21. Roccaro, P.; Lombardo, G.; Vagliasindi, F.G.A. Offline bioregeneration of spent activated carbon loaded with real Produced Water and its adsorption capacity for benzene and toluene. Desalin. Water Treat. 2015, 55, 756-766. [CrossRef]

22. Doyle, D.; Brown, A. Produced water treatment and hydrocarbon removal with organoclay. Soc. Pet. Eng. 2000, 1-11. [CrossRef]

23. Means, C.M.; Braden, M.L. Process for Removing Water Soluble Organic Compounds from Produced Water. U.S. Patent 5,104,545, 14 April 1992.

24. Campo, R.; Di Prima, N.; Freni, G.; Giustra, M.G.; Di Bella, G. Start-up of two moving bed membrane bioreactors treating saline wastewater contaminated by hydrocarbons. Water Sci. Technol. 2016, 73. [CrossRef]

25. Kargi, F.; Uygur, A. Improved nutrient removal from saline wastewater in an SBR by Halobacter supplemented activated sludge. Environ. Eng. Sci. 2005, 22, 170-176. [CrossRef]

26. Kargi, F.; Konya, I. COD, para-chlorophenol and toxicity removal from para-chlorophenol containing synthetic wastewater in an activated sludge unit. J. Hazard. Mater. 2006, 132, 226-231. [CrossRef] [PubMed]

27. Freire, D.D.C.; Cammarota, M.C.; Sant'Anna, G.L. Biological treatment of oil field wastewater in a sequencing batch reactor. Environ. Technol. 2001, 22, 1125-1135. [CrossRef] [PubMed]

28. Tellez, G.T.; Nirmalakhandan, N. Bioreclamation of oilfield produced wastewaters: Characterization and feasibility study. In Produced Water; Ray, J.P., Engelhardt, F.R., Eds.; Springer: New York, NY, USA, 1992; pp. 523-533.

29. Cheryan, M.; Rajagopalan, N. Membrane processing of oily streams. Wastewater treatment and waste reduction. J. Memb. Sci. 1998, 151, 13-28. [CrossRef]

30. Judd, S.; Judd, C. The MBR Book: Principles and Applications of Membrane Bioreactors for Water and Wastewater Treatment, 2nd ed.; Elsevier: Amsterdam, The Netherlands, 2011.

31. Soltani, S.; Mowla, D.; Vossoughi, M.; Hesampour, M. Experimental investigation of oily water treatment by membrane bioreactor. Desalination 2010, 250, 598-600. [CrossRef]

32. Jang, D.; Hwang, Y.; Shin, H.; Lee, W. Effects of salinity on the characteristics of biomass and membrane fouling in membrane bioreactors. Bioresour. Technol. 2013, 141, 50-56. [CrossRef] [PubMed]

33. Johir, M.A.H.; Vigneswaran, S.; Kandasamy, J.; BenAim, R.; Grasmick, A. Effect of salt concentration on membrane bioreactor (MBR) performances: Detailed organic characterization. Desalination 2013, 322, 13-20. [CrossRef]

34. Pendashteh, A.R.; Abdullah, L.C.; Fakhru'L-Razi, A.; Madaeni, S.S.; Zainal Abidin, Z.; Awang Biak, D.R. Evaluation of membrane bioreactor for hypersaline oily wastewater treatment. Process. Saf. Environ. Prot. 2012, 90, 45-55. [CrossRef]

35. Ødegaard, H. Innovations in wastewater treatment: The moving bed biofilm process. Water Sci. Technol. 2006, 53, 17-33. [CrossRef] [PubMed] 
36. Di Trapani, D.; Di Bella, G.; Mannina, G.; Torregrossa, M.; Viviani, G. Comparison between moving bed-membrane bioreactor (MB-MBR) and membrane bioreactor (MBR) systems: Influence of wastewater salinity variation. Bioresour. Technol. 2014, 162, 60-69. [CrossRef] [PubMed]

37. Leyva-Díaz, J.C.; Calderón, K.; Rodríguez, F.A.; González-López, J.; Hontoria, E.; Poyatos, J.M. Comparative kinetic study between moving bed biofilm reactor-membrane bioreactor and membrane bioreactor systems and their influence on organic matter and nutrients removal. Biochem. Eng. J. 2013, 77, 28-40. [CrossRef]

38. Kose-Mutlu, B.; Ersahin, M.E.; Ozgun, H.; Kaya, R.; Kinaci, C.; Koyuncu, I. Influence of powdered and granular activated carbon system as a pre-treatment alternative for membrane filtration of produced water. J. Chem. Technol. Biotechnol. 2017, 92, 283-291. [CrossRef]

39. Nguyen, S.T.; Roddick, F.A. Pre-treatments for removing colour from secondary effluent: Effectiveness and influence on membrane fouling in subsequent microfiltration. Sep. Purif. Technol. 2013, 103, 313-320. [CrossRef]

40. Dialynas, E.; Diamadopoulos, E. Integration of immersed membrane ultrafiltration with coagulation and activated carbon adsorption for advanced treatment of municipal wastewater. Desalination 2008, 230, 113-127. [CrossRef]

41. Gur-Reznik, S.; Katz, I.; Dosoretz, C.G. Removal of dissolved organic matter by granular-activated carbon adsorption as a pretreatment to reverse osmosis of membrane bioreactor effluents. Water Res. 2008, 42, 1595-1605. [CrossRef] [PubMed]

42. American Public Health Association (APHA); American Water Works Association (AWWA); World Economic Forum (WEF). Standard Methods for the Examination of Water and Wastewater; American Public Health Association: Washington, DC, USA, 2012.

43. US EPA. Epa Method 3510C: Separatory Funnel Liquid-Liquid Extraction; Test Methods For Evaluating Solid Waste Physicalchemical Methods; United States Environmental Protection Agency: Washington, DC, USA, 1996; pp. 1-8.

44. Tchobanoglous, G.; Burton, F.L.; Stensel, H.D. Wastewater Engineering: Treatment and Reuse; Metcalf \& Eddy, Inc.: Wakefield, MA, USA, 2003; Volume 4.

45. American Public Health Association (APHA). Standard Methods for the Examination of Water and Wastewater; American Public Health Association: Washington, DC, USA, 2005. 